García-Carrasco, J.-M., W. Tapia and A.-R. Muñoz. 2020. Roadkill of birds in Galapagos Islands: a growing need for solutions. Avian Conservation and Ecology 15(1):19. https://doi.org/10.5751/ACE-01596-150119

Copyright (C) 2020 by the author(s). Published here under license by the Resilience Alliance.

Short Communication

\title{
Roadkill of birds in Galapagos Islands: a growing need for solutions
}

José-María García-Carrasco ${ }^{1}$, Washington Tapia ${ }^{2}$ and Antonio-Román Muñoz ${ }^{1}$

${ }^{1}$ University of Málaga, ${ }^{2}$ Galapagos Conservancy

\begin{abstract}
A major step in the development of conservation measures would be to study and understand the sources of non-natural mortality in wild fauna. The implementation of such measures should be a priority in oceanic islands because biodiversity hotspots are concentrated in these locations. Furthermore, anthropogenic changes have a greater impact on island species than on their mainland relatives. This situation is of particular relevance in the Galápagos Archipelago, owing to its rapid population growth and the striking increase in the number of vehicles. The latter aspect is due to attempts by the tourist industry to stimulate the economy in this area. Thus, the environment and biota are under new pressures. There are few studies on the effects of wildlife roadkill in the Galápagos. We surveyed two stretches of a 13.8-km road in two different vegetation zones on the island of Santa Cruz. This island has the highest population and the greatest number of tourists in the archipelago. We determined the spatial patterns of bird roadkill using counts, which were conducted via bicycle rides. We recorded 168 carcasses comprising seven species (six native and one invasive). Roadkill did not occur at the same rate over the two stretches: it was significantly higher over Stretch 1, which had a greater volume of traffic. Neither were species equally distributed over the stretches. We identified a high-mortality black spot within Stretch 1 in an area in which high-speed traffic may have contributed strongly to roadkill. We also estimated the carcass disappearance rate to better determine the roadkill rate. Data on the disappearance rate could be of help in the design and implementation of future studies. This study presents the first data on the road mortality rate in the Galápagos Islands, finding that it is much higher than in other natural areas. This represents a first step toward minimizing the growing threat to Galápagos birds, and provides a basis for future research on conservation management plans in the Galápagos Islands.
\end{abstract}

\section{Mortalité d'oiseaux par collision avec les véhicules sur les îles Galápagos : besoin pressant de solutions}

RÉSUMÉ. L'étude et la compréhension des sources de mortalité non-naturelle de la faune sauvage représenteraient un grand pas dans l'élaboration de mesures de conservation. La mise en oeuvre de mesures de ce genre devrait être priorisée sur les îles océaniques parce que ces dernières sont souvent des points chauds de biodiversité. De plus, les changements d'origine anthropique ont un impact plus important sur les espèces insulaires que sur leurs conspécifiques continentaux. Cette situation est particulièrement vraie dans l'archipel des Galápagos, en raison de la croissance démographique rapide et de l'accroissement frappant du nombre de véhicules qu'on y observe. Ces deux phénomènes sont attribuables aux tentatives de l'industrie touristique pour stimuler l'économie de ce secteur, l'environnement et le biote subissant ainsi de nouvelles pressions. Il existe peu d'études sur les effets des collisions de la faune avec les véhicules aux Galápagos. Nous avons inventorié deux tronçons d'une route de 13,8 km situés dans des zones de végétation différente sur l'île de Santa Cruz. Cette île est la plus peuplée et la plus touristique de l'archipel. Nous avons déterminé la répartition spatiale des mortalités d'oiseaux par collision au moyen de dénombrements, qui ont été réalisés par virée en bicyclette. Nous avons noté 168 carcasses provenant de sept espèces (six indigènes et une envahissante). Les mortalités par collision ne se sont pas produites au même taux sur les deux tronçons : le taux était considérablement plus élevé dans le Tronçon 1, lequel avait un volume plus élevé de circulation. Les espèces n'étaient pas non plus réparties de la même façon dans les tronçons. Nous avons identifié un point noir de mortalité élevée dans le Tronçon 1, dans un secteur où la circulation à grande vitesse a peut-être contribué grandement aux collisions. Nous avons aussi estimé le taux de disparition des carcasses afin de mieux déterminer le taux de collision par véhicule. Les données obtenues sur le taux de disparition pourraient servir à l'élaboration et à la mise en oeuvre de futures études. La présente étude fait état des premières données sur le taux de mortalité par collision dans les îles Galápagos, lequel est beaucoup plus élevé que dans d'autres milieux naturels. Il s'agit là d'une première étape en vue d'endiguer la menace croissante que subissent les oiseaux des Galápagos, et d'un fondement sur lequel les futures recherches en lien avec les plans de gestion de conservation dans les îles Galápagos pourront se baser.

Key Words: conservation; endemic species; human-wildlife conflicts; island biodiversity; threats

\section{INTRODUCTION}

Road transport has become a basic pillar of economic and social life. Nevertheless, roadways are associated with habitat degradation and often act as barriers that have adverse ecological consequences. The more common environmental impacts of roads include traffic noise (Reijnen et al. 1995), habitat fragmentation
(Bélisle and St. Clair 2001), reduced habitat quality (Laurance et al. 2009), spread of exotic species (Western and Juvik 1983, Forman and Alexander 1998), and roadkill (Trombulak and Frissell 2000). Although most studies on this problem have been conducted in temperate areas (Monge-Nájera 2018), it is also severe in tropical regions. 
The Galápagos Islands are a unique ecosystem and a symbolic conservation area in which human activities have had a minimal effect on ecological and evolutionary processes (González et al. 2008). However, these activities are threatening biodiversity in the archipelago, especially on the inhabited islands (Izurieta et al. 2018). Conflict exists between effective environmental policies, recent population growth, and the introduction and establishment of invasive species. The human population has grown from 1346 inhabitants in 1950 (Kricher 2006) to 25,244 in 2016 (INEC 2016). There has been an increase not only in the number of residents, but also in the number of tourists, which rose from 70,000 visitors/ y in 1999 (Charles Darwin Foundation and World Wildlife Fund 2002) to 275,817/y in 2018 (Dirección del Parque Nacional Galápagos \& Observatorio de Turismo de Galápagos 2018). Santa Cruz is the most heavily populated island in the archipelago with more than $60 \%(15,701)$ of the entire population of the Galápagos Islands (INEC 2016). Thus, this island is experiencing the greatest adverse consequences of anthropization. For example, Santa Cruz harbors the greatest number of non-native plant species (670) in the archipelago (Tye et al. 2008, Rivas-Torres et al. 2018). The number of vehicles in Santa Cruz rose from 28 in 1980 (Márquez 2000), to 1074 in 2006 (Villa 2008, Oviedo et al. 2009), and to 1326 in 2013. In addition, the state of the roads has been improved over time with the main road being fully paved in 2000 (Tanner and Perry 2007). As a result, there has been an increase in negative impacts on fauna, and this situation will probably worsen because of future socioeconomic improvements. Because of its isolation, insular wildlife is more susceptible than its mainland relatives to anthropogenic alterations (Whittaker and Fernández-Palacios 2007). As an example, in Lord Howe Island, road mortality has been identified as an important threat to the Flesh-footed Shearwater (Puffinus carneipes) population (Reid et al. 2013). The Galápagos Islands are one of the Priority Ecoregions for Global Conservation because of the exceptionally high concentration of endemic species (Olson and Dinerstein 2002). Although bird roadkill has been studied worldwide (Erritzoe et al. 2003, Husby 2016), few empirical studies have described the extent of bird roadkill in the Galápagos Islands (see Carvajal 1980, Llerena et al. 2001, Jiménez-Uzcátegui and Betancourt 2005, 2006, 2008). Such studies have generally appeared in the form of reports rather than peer-reviewed journals articles.

The aim of this study was to offer a first approach to the effect of roads on avifauna in the Galápagos Islands and to highlight the need for studies on the balance between social development and fauna conservation. To this end, we analyzed the spatial distribution of bird roadkill on the most-populated island (Santa Cruz) in the archipelago. We evaluated species composition along two stretches of two types of roads running through two different vegetation zones. We also estimated carcass persistence time in diverse conditions to better understand the growing threat of roadkill.

\section{METHODS}

\section{Study area}

The Galápagos Archipelago is located approximately $1000 \mathrm{~km}$ west of South America (Trueman and D'Ozouville 2010) and comprises 16 main islands (Snell et al. 1995, Miller et al. 2010; Fig. 1). The present study was conducted on Santa Cruz, which is the most populated island in the Archipelago. In total, $88 \%$ of the surface area of this island $\left(985.55 \mathrm{~km}^{2}\right)$ is protected as part of the Galápagos National Park (Servicio Parque Nacional Galápagos 2006). As a result of different precipitation and temperature patterns, altitudinal zonation determines climatic differences in the islands (Reeder and Riechert 1975). The surveyed road $(13.8 \mathrm{~km})$ crossed two out of the six vegetation zones in Santa Cruz (Wiggins and Porter 1971, Dvorak et al. 2012): (a) the dry zone with a southern slope (0-120 masl; transect $=4.31 \mathrm{~km}$ ), characterized by forest and scrubland dominated by palo santo (Bursera graveolens), cacti (Opuntia echios), and various shrub species; and (b) the transition zone (120-300 masl; transect $=9.49 \mathrm{~km})$, where pega-pega $($ Pisonia floribunda $)$ and guayabillo (Psidium galapageiums) dominate the humid forest.

Fig. 1. Study area in the Galápagos Islands. Black lines represent roads crossing Santa Cruz Island. Red polygons represent buildings situated between Puerto Ayora and El Cascajo.

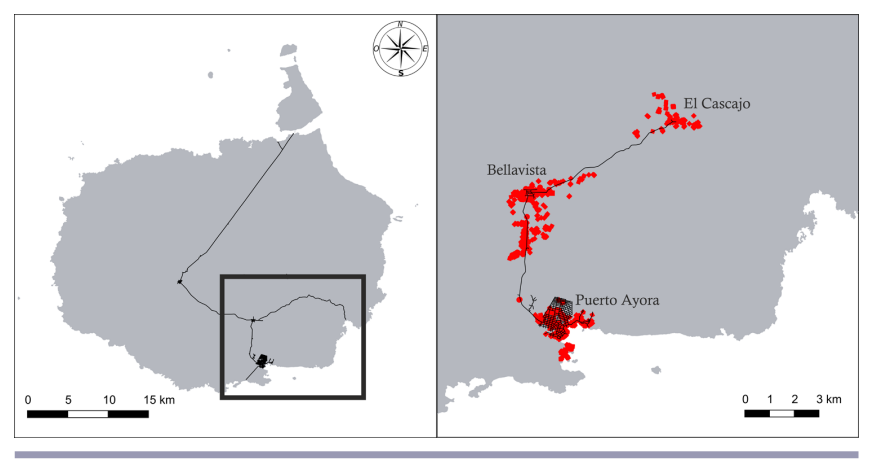

\section{Mortality monitoring}

During July 2017, we surveyed on 14 occasions on alternate days the two stretches of road. Stretch $1(6.84 \mathrm{~km})$ ran along the cycle path by the Avenue Padre Julio Herrera from Puerto Ayora ( 0 masl) to Bellavista (180 masl), and Stretch $2(6.96 \mathrm{~km})$ ran along the Vía Playa Garrapatero from Bellavista (180 masl) to El Cascajo (260 masl). The two stretches are in different states of repair and traffic. Stretch 1 is a well-paved road and is mainly used by taxis, buses, and trucks. The percentages of types of transport in the island are as follows: motorcycles (46\%), pickups $(35 \%$, mostly used as taxis), typical transport vehicles $(5 \%)$, trucks $(6 \%)$, and private cars and special vehicles ( $8 \%$ ) (Consejo de Gobierno del Régimen Especial de Galápagos 2016). Stretch 1 is in more frequent use than Stretch 2 and connects the main city of the island with the Itabaca Channel, where tourists and merchandise are frequently collected and transported by typical transport vehicles, trucks, and taxis. However, although Stretch 2 is paved, it is in worse condition than Stretch 1. It is much less travelled and is mainly used by local residents to reach farming areas and by taxi drivers to access Garrapatero beach. Given the deteriorated state of road surface on Stretch 2, vehicle speed on this stretch is lower than on the Stretch 1.

We determined the spatial patterns of bird roadkill using carcass counts, which were conducted via bicycle rides (average speed, 7$8 \mathrm{~km} / \mathrm{h}$ ). We determined the geographic coordinates of each bird carcass using a Garmin GPSMAP 78 GPS navigator. We also recorded the date when each carcass was found and removed, the 
Table 1. Number of species found along the two stretches (sex and age provided where possible). Species were ordered following the Handbook of Birds of the World/Cornell Lab taxonomy.

\begin{tabular}{|c|c|c|c|c|c|c|c|c|c|c|}
\hline \multirow[t]{2}{*}{ Common Name } & \multirow[t]{2}{*}{ Scientific Name } & \multirow[t]{2}{*}{ Total } & \multicolumn{2}{|c|}{ Stretches } & \multicolumn{3}{|c|}{ Sex } & \multicolumn{3}{|c|}{ Age } \\
\hline & & & Stretch 1 & Stretch 2 & Male & Female & Unknown & Adult & Juvenile & Unknown \\
\hline Smooth-billed Ani & Crotophaga ani & 8 & 3 & 5 & 0 & 0 & 8 & 1 & 0 & 7 \\
\hline Galapagos Mockingbird & Mimus parvulus & 8 & 8 & 0 & 0 & 0 & 8 & 1 & 3 & 4 \\
\hline Yellow Warbler & Setophaga petechia aureola & 112 & 92 & 20 & 32 & 28 & 52 & 77 & 25 & 10 \\
\hline Vegetarian Finch & Platyspiza crassirostris & 1 & 1 & 0 & 0 & 0 & 1 & 0 & 1 & 0 \\
\hline Small Tree-Finch & Camarhynchus parvulus & 3 & 1 & 2 & 0 & 1 & 2 & 1 & 2 & 0 \\
\hline Small Ground-Finch & Geospiza fuliginosa & 16 & 6 & 10 & 2 & 5 & 9 & 8 & 8 & 0 \\
\hline Medium Ground-Finch & Geospiza fortis & 4 & 4 & 0 & 1 & 2 & 1 & 3 & 1 & 0 \\
\hline Unknown Finch & & 16 & 10 & 6 & 4 & 0 & 12 & 6 & 4 & 6 \\
\hline Total & & 168 & 125 & 43 & 39 & 36 & 93 & 97 & 44 & 27 \\
\hline
\end{tabular}

species, and, when possible, its sex and age. Adults were defined as birds that were alive in the year following the hatching year. Darwin's Small Tree-Finches (Camarhynchus parvulus) were aged by the proportion of black feathers in the chin and crown (Kleindorfer 2007), whereas Small Ground-Finches (Geospiza fuliginosa) were aged by the proportion of black feathers in the body plumage (Price 1984). We only sexed adult Darwin's finches because young males are indistinguishable from females by plumage coloration. Adult Yellow Warblers (Setophaga petechia aureola) were recognized by their intense yellowish-green color, and juveniles by their olive-grey crown, paler underparts, and lack of intense yellow tones. Males of this species have a visible rufous cap and well-defined rufous streaks on their flanks, whereas females lack the rufous cap, have unstreaked underparts, and have a general duller appearance (personal observations). Subsequently, the disappearance rate was estimated according to persistence time. Starting from the length of the stretches surveyed, we calculated the carcass density (carcasses $/ \mathrm{km}$ ) along them. Taking into account that the surveys were carried out in one month, our approach to calculate the annual mortality rate was done by multiplying the carcass density on each stretch by 12 , the number of months in a year.

\section{Statistical analyses}

All statistical analyses were conducted using the Statistical Package for the Social Sciences (IBM SPSS Statistics v.25). Kaplan-Meier persistence curves were used to estimate carcass removal by scavengers (Kaplan and Meier 1958, White and Garrott 1990). The log-rank test was used to (a) compare the carcass disappearance rate over Stretch 1 (from Puerto Ayora to Bellavista) and Stretch 2 (from Bellavista to El Cascajo), (b) compare carcass persistence time in the two vegetation zones, i.e., the dry and transition zones, and (c) compare carcass persistence time over Stretch 1 and Stretch 2 according to body size. Others studies have found an association between disappearance rates and body size (Kostecke et al. 2001, Prosser et al. 2008, Smallwood et al. 2010, Urquhart et al. 2015, Farfán et al. 2017). Thus, carcasses were classified into three categories to test this hypothesis: from $7 \mathrm{~g}$ to $20 \mathrm{~g}$; from $21 \mathrm{~g}$ to 40 $\mathrm{g}$; and more than $40 \mathrm{~g}$.

\section{RESULTS}

We found 168 bird carcasses (12.17 carcasses $/ \mathrm{km}$ ) between Puerto Ayora and El Cascajo. The carcasses comprised four families (Cuculidae, Mimidae, Parulidae, and Thraupidae). We recorded seven species (Table 1), the most abundant being the Yellow
Warbler (112 carcasses), and the least abundant being the Vegetarian Finch (Platyspiza crassirostris; 1 carcass). All species/ subspecies are endemic to the archipelago except for the Smoothbilled Ani (Crotophaga ani), which is an exotic invasive species in the Galapagos. Regarding conservation status, all species are of least concern (LC; BirdLife International 2018). Population sizes for species recorded and nonrecorded in this study are shown in Table 2.

Table 2. Population size according to Dvorak et al. 2012 for species recorded during the roadkill study on Santa Cruz, as well as the species present on the study area but not recorded as roadkill. Species were ordered following the Handbook of Birds of the World/Cornell Lab taxonomy.

\begin{tabular}{llc}
\hline \hline Common name & Scientific name & $\begin{array}{c}\text { Population size } \\
\text { (singing males) }\end{array}$ \\
\hline Smooth-billed Ani & Crotophaga ani & - \\
Galapagos Mockingbird & Mimus parvulus & 76,500 \\
Yellow Warbler & Setophaga petechia aureola & 156,300 \\
Vegetarian Finch & Platyspiza crassirostris & 41,300 \\
Small Tree-Finch & Camarhynchus parvulus & 176,800 \\
Small Ground-Finch & Geospiza fuliginosa & 388,300 \\
Medium Ground-Finch & Geospiza fortis & 271,400 \\
Unknown Finch & & - \\
& & \\
Nonrecorded species during the sample period & - \\
Galapagos Dove & Zenaida galapagoensis & 6500 \\
Dark-billed Cuckoo & Coccyzus melacoryphus & - \\
Paint-billed Crake & Neocrex erythrops & - \\
Cattle Egret & Bubulcus ibis & - \\
Barn Owl & Tyto alba punctatissima & - \\
Short-eared Owl & Asio flammeus galapagoensis & 157,200 \\
Galapagos Flycatcher & Myiarchus magnirostris & 55,500 \\
Green Warbler-Finch & Certhidea olivacea & 8900 \\
Large Tree-Finch & Camarhynchus psittacula & 11,600 \\
Woodpcker Finch & Camarhynchus pallidus & - \\
Large Ground-Finch & Geospiza magnirostris & 95,700 \\
Common Cactus-Finch & Geospiza scandens & \\
\hline & &
\end{tabular}

We found roadkill over the entire length of the road. However, there were differences in the amount of roadkill between the two stretches. Stretch 1 contained 125 carcasses (18.27 carcasses $/ \mathrm{km}$ ), and Stretch 2 contained 43 carcasses $(6.18$ carcasses $/ \mathrm{km})$. The fourth kilometer on Stretch 1 contained a very high carcass density (49 carcasses/km; Fig. 2). The estimated annual roadkill was 219.24 carcasses $/ \mathrm{km} / \mathrm{y}$ in Stretch 1 and 74.16 carcasses $/ \mathrm{km} / \mathrm{y}$ in Stretch 2. 
Fig. 2. Roadkill locations (black dots) of the affected species along the Stretch 1 (from Puerto Ayora to Bellavista) and Stretch 2 (from Bellavista to El Cascajo). Each stretch is divided into one kilometer segments (red point: from 1 to 6 ). Brown line indicates the limit between the dry zone (on the south) and the transition zone (on the north).

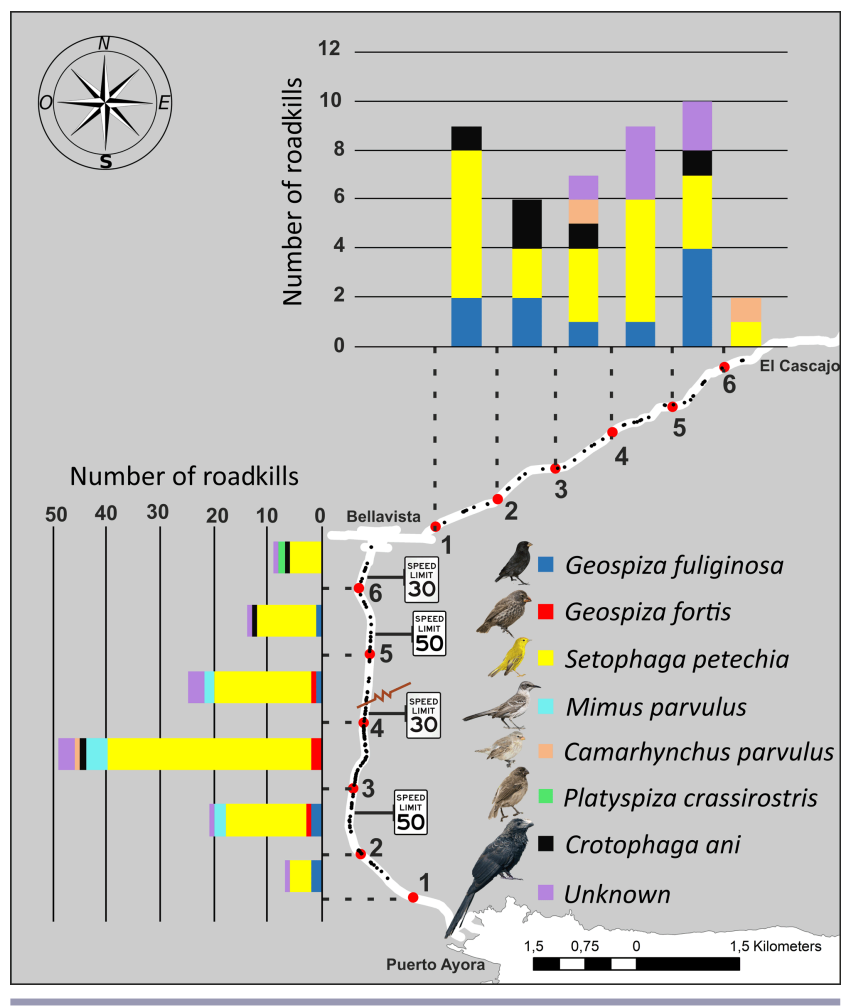

Significant differences were found between the ages of roadkilled birds. The number of adult roadkilled birds was more than double that of young birds. However, there were no differences between sexes. We recorded dead Yellow Warblers over the entire route, i.e., Stretches 1 and 2. Nevertheless, the roadkill concentration of this species was higher in Stretch 1 (Fig. 2). Similarly, we recorded roadkilled finches over the two stretches, but there were differences in the number of carcasses between the vegetation zones. In the transition zone ( $>120$ masl), we recorded three out of the four roadkilled Tree Finches, and 12 out of the 16 roadkilled Small Ground-Finches, whereas in the dry zone we recorded three out of the four roadkilled Medium Ground-Finches (Geospiza fortis) (Fig. 2). There was a similar difference between Galapagos Mockingbirds (Mimus parvulus) and Smooth-billed Ani (Crotophaga anis). Seven out of the eight roadkilled Galapagos Mockingbirds were detected in the dry zone, whereas seven out of the eight roadkilled Smooth-billed Ani were found in the transition zone (Fig. 2).

In relation to total road kills (168) over both stretches, the disappearance rate analysis showed that the average persistence was $13.33 \pm 0.95$ days with a median of seven days, according to the Kaplan-Meier curves. Regarding disappearance rates, no significant differences were found between the two stretches: Stretch 1, 125 road kills, $12.80 \pm 1.07$ days; Stretch 2, 43 road kills, $11.88 \pm 1.38$ days $(P=0.305$; Fig. 3$)$ or between vegetation zones: dry zone, 89 road kills, $11.95 \pm 1.23$ days; transition zone, 79 road kills, $15.12 \pm 1.45$ days $(P=0.091)$. No significant associations were found between scavenger removal rates and body size: $7 \mathrm{~g}$ to $20 \mathrm{~g}$ (131 road kills), $12.60 \pm 1.06$ days; $21 \mathrm{~g}$ to $40 \mathrm{~g}$ (5 road kills), $8.25 \pm 3.38$ days; and more than $40 \mathrm{~g}$ (16 road kills $), 16.66 \pm 3.18$ days $(P=0.534)$.

Fig. 3. Persistence curves in days to removal over the two stretches. The black line (1) represents the persistence curve for Stretch 1 and the grey line (2) represents the curve for Stretch 2. Perpendicular lines indicate censored carcasses (still intact at the last check) for each stretch.

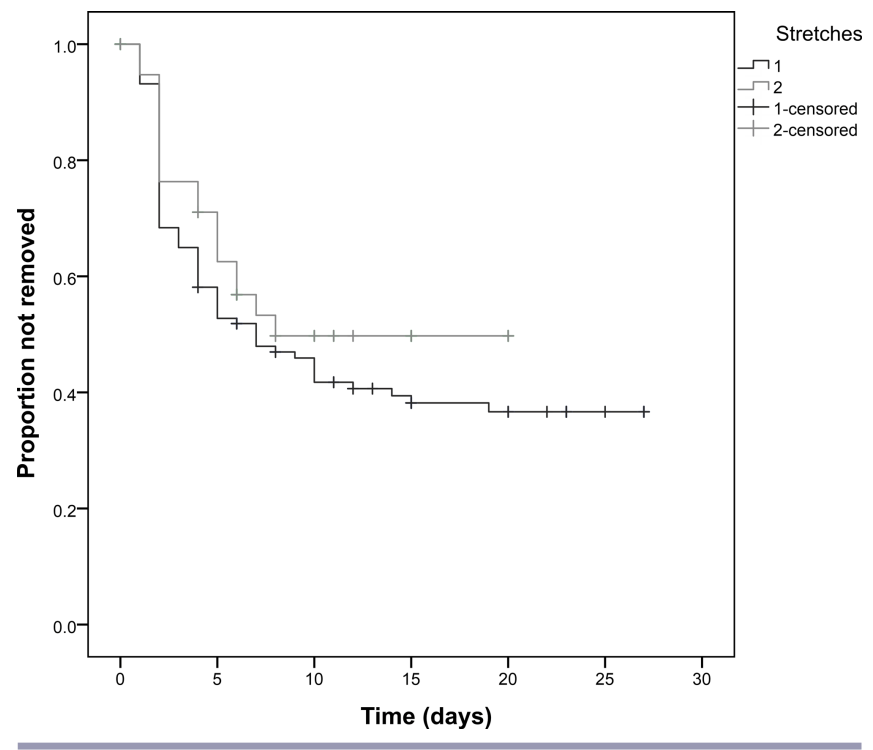

\section{DISCUSSION}

Insular ecosystems are susceptible to human impacts because increases in mortality caused by these impacts may adversely affect the demography of insular populations (Biber 2002, Donázar et al. 2005). The effect of roads on fauna is of particular interest, especially on islands that are under increasing pressure. Although many oceanic islands in the Pacific have lost most of their endemic birds (Steadman 2007), the Galápagos Islands have preserved their avifauna intact (Jiménez-Uzcátegui and Betancourt 2008). However, the conservation status of some of the endemic species is changing. These species include the Mangrove Finch (Geospiza heliobates) and the Galapagos Petrel (Pterodroma phaeopygia), which are at present critically endangered (BirdLife International 2018). The situation is even more critical on inhabited islands because of habitat destruction and the introduction of alien species and diseases. Floreana Island has recently experienced decreases in populations of birds, such as the Small Tree-Finch or Medium Ground-Finch (Dvorak et al. 2017), while on Santa Cruz there have been similar decreases in the populations of Yellow Warbler and Vegetarian Finch (Dvorak et al. 2012).

\section{Affected birds and their distributions}

Previous studies demonstrated that the Small Ground-Finch was the species most affected by road mortality on the island of Santa 
Cruz (Carvajal 1980). However, subsequent reports suggested that the Yellow Warbler was the most-affected species (Llerena et al. 2001, Jiménez-Uzcátegui and Betancourt 2005, 2006, 2008; and the present study). Other species such as the Galapagos Flycatcher, despite its abundance on the island (Table 2) were not recorded as roadkill in our study. Former reports found Galapagos Flycatchers at low numbers, representing from $4 \%$ to $0.6 \%$ of total road mortality (Llerena et al. 2001, JiménezUzcátegui and Betancourt 2005, 2006). Although we do not really have a clear explanation, its absence might be because of the limitation in time of our study, to the low number of birds along the surveyed stretches during the dry period, to a differential behavior when facing the crossing of roads, or to a combination of the aforementioned aspects.

Even though these results are relatively conservative, the annual mortality rate found in the Galapagos was very high compared to the rates found by other studies. Estimated mortality rates in the high Andes (Ecuador) were 4 individuals $/ \mathrm{km} / \mathrm{y}$ (Aguilar et al. 2019), 21.9 individuals $/ \mathrm{km} / \mathrm{y}$ in southern Brazil (da Rosa and Bager 2012), and 29.49 individuals/ $\mathrm{km} / \mathrm{y}$ in Lanzarote, Canary Islands (Spain; Tejera et al. 2018). In Santa Cruz, the mortality rate was 219.24 individuals $/ \mathrm{km} / \mathrm{y}$ and 74.16 individuals $/ \mathrm{km} / \mathrm{y}$ on Stretches 1 and 2, respectively. These roadkill rates are obviously severe and mainly affect all endemic species, except for the Smooth-billed Ani.

Concerning the distribution of roadkill by species, Galapagos Mockingbirds and Medium Ground-Finches were mainly confined to lower elevations. This result is in line with the observations of Dvorak et al. (2012). The only invasive bird recorded was the Smooth-billed Ani, which was mainly found in the transition zone. Populations of this species are greater in this zone than in the dry zone (Rosenberg et al. 1990, Cooke et al. 2019). These three species appear to inhabit a well-defined altitudinal range. In fact, only one individual from each of these three species was found outside of its apparent altitudinal range, and all three individuals were found within the limits of an imaginary line separating both zones (Fig. 2). Therefore, the type of roadkill detected over the two stretches could provide an estimation of the different species distribution over the surveyed area.

\section{Disappearance rate}

Persistence curves showed that carcass persistence time was not affected by type of stretch, vegetation zone, or body size; that is, the carcass removal rate did not vary according to the place where they were found or to carcass size. This result is in contrast to those of other studies (Urquhart et al. 2015, Farfán et al. 2017). Scavengers remove carcasses, thus leading to roadkill being underestimated. In the study area, the community of scavengers may not select the carcasses found along the road according to body size. As proposed by Kostecke et al. (2001), this result suggests that carcasses are opportunistically found by scavengers. The first observation of the Cattle Egret (Bubulcus ibis) occurred in 1964 on Santa Cruz Island (Lévêque et al. 1966). Since then, this species has settled in the main islands of the archipelago (BirdLife International 2018). Given their foraging behavior, Cattle Egrets and cats may now be the main scavengers. Future studies could use estimated persistence time to provide a more accurate estimation of roadkill. They could also use appropriate search intervals to avoid underestimating the number of dead animals because it is known that $50 \%$ of birds disappear within 7 days following a fatal collision with a vehicle.

\section{Speed and mortality black spots}

Because of the characteristics inherent to both stretches, i.e., state of the road and frequency of vehicles, it would seem natural to find more carcasses on the stretch with faster traffic. Nevertheless, the number of carcasses was not evenly distributed over the entire road. Moreover, there is an uneven distribution of buildings near the road and road signals along it. There is a $1-\mathrm{km}$ section in which the number of carcasses was remarkably high (39\% of the total on Stretch 1). Bird roadkill on this black spot is higher because of the lack of buildings and road signals, which encourages drivers to drive faster. One study found that speed was a major contributor to the deadliest road segments (Tejera et al. 2018). In fact, speed and traffic density have been found to be relevant contributors to bird roadkill (Dunthorn and Errington 1964, Erritzoe et al. 2003). However, on roads with high speed limits and low traffic density, it has been found that speed, rather than traffic density, has a greater impact on roadkill (Haas 1964). Similarly, Martens (1962) found no significant association between traffic density and bird roadkill. However, Martens suggested that birds were killed by a small number of very fast cars. Consequently, we suggest that speed is a determining factor in road mortality in the Galápagos Islands. There are four maximum speed limit signs on the road between Puerto Ayora and Bellavista, with $50 \mathrm{~km} / \mathrm{h}$ and a $30 \mathrm{~km} / \mathrm{h}$ speed limit signs 300 $\mathrm{m}$ before and on either side of the black spot (Fig. 2). However, speed remains a problem, even though several technical reports on the island have concluded that speed needs to be reduced. In fact, speed control systems have led to satisfactory results in Madagascar, where speed bumps have been tested (Schutt 2008), and in Tikal, Guatemala, where vehicles are recorded by officers at the beginning and end of the road to guarantee adherence to speed limits (personal observation).

We highlight the relevance of conducting future studies on the entire road, which runs longitudinally over the island from Puerto Ayora to the Itabaca Channel. We have personal anecdotal information on other roadkill species recorded on the road from Bellavista to the Itabaca Channel, such as the Barn Owl (Tyto alba punctatissima), Dark-billed Cuckoo (Coccyzus melacoryphus), Paint-billed Crake (Neocrex erythrops), Galapagos Flycatcher (Myiarchus magnirostris), and a very large number of Darwin's finches. This study, together with future work, will contribute to planning improved traffic management measures. It is a far from easy task to control the number of vehicles in an area that is undergoing socioeconomic growth. Nevertheless, the implementation of traffic speed controls could reduce avian roadkill in the Galápagos Islands at little cost.

\section{CONCLUSION}

The present study found that road traffic has a severe direct impact on insular avifauna on the island of Santa Cruz, involving the highest mortality rate ever reported in insular complexes and other natural areas. Avian roadkill comprised six native species and one invasive species during the study period. Of these seven species, the Yellow Warbler was the bird most affected by road mortality. The amount of roadkill was higher on the road from 
Puerto Ayora to Bellavista than on the road from Bellavista to El Cascajo. Carcass density was higher in the zones in which vehicles can circulate faster, such as Stretch 1 and the black spot within this stretch. The number of carcasses found is likely related to speed. The results of this study highlight the need for further research on the impact of roads on Galápagos wildlife. We suggest that there is an urgent need to implement traffic management measures aimed at reducing the speed of vehicles in order to protect and preserve biodiversity in the Galápagos.

Responses to this article can be read online at: http://www.ace-eco.org/issues/responses.php/1596

\section{Acknowledgments:}

We thank the University of Malaga, the Agencia Andaluza de Cooperación Internacional (Junta de Andalucía), and Galapagos Conservancy for giving us the opportunity to do this study in the Galapagos Islands and facilitate the necessary permits. We would also like to thank Charles Darwin Foundation, especially Gustavo Jiménez-Uzcátegui, David Anchundia, and Birgit Fessl, for their support. This research did not receive any specific grant from funding agencies in the public, commercial, or not-for-profit sectors. ARM was partially supported by the project UMA18FEDERJA-276, partially financed by the European Social Fund.

\section{LITERATURE CITED}

Aguilar, J. M., A. Nieto, N. Espinoza, G. Loja, and B. A. Tinoco. 2019. Assessing patterns of bird roadkills in a high Andean Ecuadorian national park. Studies on Neotropical Fauna and Environment 54:149-156. https://doi.org/10.1080/01650521.2019.1649953

Bélisle, M., and C. C. St. Clair. 2001. Cumulative effects of barriers on the movements of forest birds. Conservation Ecology 5(2):9. https://doi.org/10.5751/ES-00312-050209

Biber, E. 2002. Patterns of endemic extinctions among island bird species. Ecography 25:661-676. https://doi.org/10.1034/j.1600-0587.2002. t01-1-250603.x

BirdLife International. 2018. The IUCN Red List of Threatened Species 2018. BirdLife International, Cambridge, UK.

Carvajal, C. 1980. Mortalidad accidental de aves terrestres en la carretera Puerto Ayora - Bellavista. Tesis previa título Ciencias Modernas. Colegio Nacional Galápagos, Puerto Ayora, Santa Cruz Island, Galápagos, Ecuador.

Charles Darwin Foundation and World Wildlife Fund. 2002. A biodiversity vision for the Galápagos Islands. R. Bensted-Smith, editor. Charles Darwin Foundation, Puerto Ayora, Galapagos.

Consejo de Gobierno del Régimen Especial de Galápagos. 2016. Plan de Desarrollo Sustentable y Ordenamiento Territorial del Régimen Especial de Galápagos. Puerto Baquerizo Moreno, Galápagos, Ecuador.

Cooke, S. C., L. E. Haskell, C. B. van Rees, and B. Fessl. 2019. A review of the introduced Smooth-billed Ani Crotophaga ani in Galápagos. Biological Conservation 229:38-49. https://doi. org/10.1016/j.biocon.2018.11.005 da Rosa, C. A., and A. Bager. 2012. Seasonality and habitat types affect roadkill of neotropical birds. Journal of Environmental Management 97:1-5. https://doi.org/10.1016/j.jenvman.2011.11.004

Dirección del Parque Nacional Galápagos \& Observatorio de Turismo de Galápagos. 2018. Informe anual de visitantes a las áreas protegidas de Galápagos del año 2017. Parque Nacional Galápagos, Santa Cruz, Galápagos, Ecuador.

Donázar, A. J. A., L. Gangoso, M. G. Forero, and J. Juste. 2005. Presence, richness and extinction of birds of prey in the Mediterranean and Macaronesian Islands. Journal of Biogeography 32:1701-1713. https://doi.org/10.1111/ j.1365-2699.2005.01294.X

Dunthorn, A. A., and F. P. Errington. 1964. Casualties among birds along a selected road in Wiltshire. Bird Study 11:168-182. https://doi.org/10.1080/00063656409476067

Dvorak, M., B. Fessl, E. Nemeth, S. Kleindorfer, and S. Tebbich. 2012. Distribution and abundance of Darwin's finches and other land birds on Santa Cruz Island, Galápagos: evidence for declining populations. Oryx 46:78-86. https://doi.org/10.1017/ S0030605311000597

Dvorak, M., E. Nemeth, B. Wendelin, P. Herrera, D. Mosquera, D. Anchundia, C. Sevilla, S. Tebbich, and B. Fessl. 2017. Conservation status of landbirds on Floreana: the smallest inhabited Galápagos Island. Journal of Field Ornithology 88:132-145. https://doi.org/10.1111/jofo.12197

Erritzoe, J., T. D. Mazgajski, and Ł. Rejt. 2003. Bird casualties on European roads - a review. Acta Ornithologica 38:77-93. https://doi.org/10.3161/068.038.0204

Farfán, M. Á., J. Duarte, J. E. Fa, R. Real, and J. M. Vargas. 2017. Testing for errors in estimating bird mortality rates at wind farms and power lines. Bird Conservation International 27:431-439. https://doi.org/10.1017/S0959270916000460

Forman, R. T. T., and L. E. Alexander. 1998. Roads and their major ecological effects. Annual Review of Ecology and Systematics 29:207-231. https://doi.org/10.1146/annurev.ecolsys.29.1.207

González, J. A., C. Montes, J. Rodríguez, and W. Tapia. 2008. Rethinking the Galapagos Islands as a complex social-ecological system: implications for conservation and management. Ecology and Society 13(2):13. https://doi.org/10.5751/ES-02557-130213

Haas, W. 1964. Verluste von Vögeln und Säugern auf Carstrassen. Ornithologische Mitteilungen 16:245-250.

Husby, M. 2016. Factors affecting road mortality in birds. Ornis Fennica 93:212-224.

Instituto Nacional de Estadistica y Censos (INEC). 2016. Censo de Población y Vivienda Galápagos, 2015. INEC, Quito, Ecuador. [online] URL: https://www.ecuadorencifras.gob.ec/galapagostiene-25-244-habitantes-segun-censo-2015/

Izurieta, A., B. Delgado, N. Moity, M. Calvopiña, I. Cedeño, G. Banda-Cruz, E. Cruz, M. Aguas, F. Arroba, I. Astudillo, D. Bazurto, M. Soria, S. Banks, S. Bayas, S. Belli, R. Bermúdez, N. Boelling, J. Bolaños, M. Borbor, M. L. Brito, L. Bucheli, K. Campbell, D. Carranza, J. Carrión, M. Casafont, X. Castro, S. Chamorro, J. Chávez, D. Chicaiza, R. Chumbi, P. Couenberg, D. Cousseau, M. Cruz, N. d'Ozouville, C. de la Guía, G. de la Torre, 
Avian Conservation and Ecology 15(1): 19

http://www.ace-eco.org/vol15/iss1/art19/

C. M. Díaz, J. Duchicela, D. Endara, V. Garcia, C. Gellibert, J. Gibbs, J. C. Guzmán, P. Heylings, A. Iglesias, J. C. Izurieta, P. Jaramillo, A. Klingman, A. Laurie, P. Leon, J. Medina, E. Mendieta, G. Merlen, C. Montalvo, E. Naula, D. Páez-Rosas, M. Peralta, M. Peralvo, M. Piu, J. Poma, J. Pontón, M. Pozo, D. Proaño, M. Ramos, A. Rousseaud, D. Rueda, P. Salinas, G. Salmoral, S. Saraguro, D. Simón-Baile, W. Tapia, B. Teran, M. Valverde, A. Vargas, J. Vega, W. Velásquez, A. Vélez, S. Verdesoto, H. G. Villarraga, F. Vissioli, C. Viteri-Mejía, L. Norris-Crespo, S. C. Cooke, M. V. Toral-Granda, and W. J. Sutherland. 2018. Corrigendum to: A collaboratively derived environmental research agenda for Galápagos. Pacific Conservation Biology 24 (2):207. https://doi.org/10.1071/PC17053_CO

Jiménez-Uzcátegui, G. A., and F. Betancourt. 2005. Estudio de la mortalidad de aves en la carretera Puerto Ayora-Canal de Itabaca 2004. Charles Darwin Foundation, Santa Cruz, Galápagos, Ecuador.

Jiménez-Uzcátegui, G. A., and F. Betancourt. 2006. Estudio de la mortalidad de aves en la carretera Puerto Ayora-Canal de Itabaca 2005. Charles Darwin Foundation, Santa Cruz, Galápagos, Ecuador.

Jiménez-Uzcátegui, G., and F. Betancourt. 2008. Bird mortality by vehicles. Galapagos Report 2007-2008:103-106.

Kaplan, E. L., and P. Meier. 1958. Nonparametric estimation from incomplete observations. Journal of the American Statistical Association 53:457-481. https://doi.org/10.1080/01621459.1958.10501452

Kleindorfer, S. 2007. Nesting success in Darwin's small tree finch, Camarhynchus parvulus: evidence of female preference for older males and more concealed nests. Animal Behaviour 74:795-804. https://doi.org/10.1016/j.anbehav.2007.01.020

Kostecke, R. M., G. M. Linz, and W. J. Bleier. 2001. Survival of avian carcasses and photographic evidence of predators and scavengers. Journal of Field Ornithology 72:439-447. https://doi. org/10.1648/0273-8570-72.3.439

Kricher, J. C. 2006. Galápagos: a natural history. Princeton University Press, Princeton, New Jersey, USA.

Laurance, W. F., M. Goosem, and S. G. W. Laurance. 2009. Impacts of roads and linear clearings on tropical forests. Trends in Ecology and Evolution 24:659-669. https://doi.org/10.1016/j. tree.2009.06.009

Lévêque, R., R. I. Bowman, and S. L. Billeb. 1966. Migrants in the Galapagos area. Condor 68:81-101. https://doi.org/10.2307/1365177

Llerena, W., H. Snell, and F. Hernán Vargas. 2001. Determinación de la distribución geográfica, densidad y mortalida de aves en la carretera Puerto Ayora-Canal de Itabaca, Santa Cruz. Charles Darwin Foundation, Santa Cruz, Galápagos, Ecuador.

Márquez, L. 2000. Mortalidad de las aves vía Puerto Ayora - Canal de Itabaca 1999. Colegio Loma Linda. Colegio Loma Linda, Puerto Ayora, Santa Cruz, Galápagos, Ecuador.

Martens, J. 1962. Gefährdung der Vogelwelt durch Kraftwagen. Ornithologische Mitteilungen 14:221.

Miller, B. W., I. Breckheimer, A. L. McCleary, L. GuzmánRamirez, S. C. Caplow, J. C. Jones-Smith, and S. J. Walsh. 2010. Using stylized agent-based models for population-environment research: a case study from the Galápagos Islands. Population and Environment 31:401-426. https://doi.org/10.1007/s11111-010-0110-4

Monge-Nájera, J. 2018. Road kills in tropical ecosystems: a review with recommendations for mitigation and for new research. Revista de Biologia Tropical 66:722-738. https://doi.org/10.15517/ rbt.v66i2.33404

Olson, D. M., and E. Dinerstein. 2002. The global 200: priority ecoregions for global conservation. Annals of the Missouri Botanical Garden 89:199-224. https://doi.org/10.2307/3298564

Oviedo, M., J. Agama, E. Buitrón, and F. Zavala. 2009. The first complete motorized vehicle census in Galapagos. Galapagos Report 2009-2010:48-53.

Price, T. D. 1984. Sexual selection on body size, territory and plumage variables in a population of Darwin's finches. Evolution 38:327-341. https://doi.org/10.1111/j.1558-5646.1984.tb00291.x

Prosser, P., C. Nattrass, and C. Prosser. 2008. Rate of removal of bird carcasses in arable farmland by predators and scavengers. Ecotoxicology and Environmental Safety 71:601-608. https://doi. org/10.1016/j.ecoenv.2007.10.013

Reeder, W. G., and S. E. Riechert. 1975. Vegetation change along an altitudinal gradient, Santa Cruz Island, Galapagos. Biotropica 7:162-175. https://doi.org/10.2307/2989621

Reid, T., M. Hindell, J. L. Lavers, and C. Wilcox. 2013. Reexamining mortality sources and population trends in a declining seabird: using Bayesian methods to incorporate existing information and new data. PLoS ONE 8(4):e58230. https://doi. org/10.1371/journal.pone.0058230

Reijnen, R., R. Foppen, C. T. Braak, and J. Thissen. 1995. The effects of car traffic on breeding bird populations in woodland. III. Reduction of density in relation to the proximity of main roads. Journal of Applied Ecology 32:187-202. https://doi. org/10.2307/2404428

Rivas-Torres, G., S. L. Flory, and B. Loiselle. 2018. Plant community composition and structural characteristics of an invaded forest in the Galápagos. Biodiversity and Conservation 27:329-344. https://doi.org/10.1007/s10531-017-1437-2

Rosenberg, D. K., M. H. Wilson, and F. Cruz. 1990. The distribution and abundance of the Smooth-billed Ani Crotophaga ani (L.) in the Galapagos Islands, Ecuador. Biological Conservation 51:113-123. https://doi.org/10.1016/0006-3207(90) 90106-Y

Schutt, P. 2008. Analysis of road kill data from Ankarafantsika National Park, Madagascar. Thesis. Duke University, Durham, North Carolina, USA.

Servicio Parque Nacional Galápagos. 2006. Plan de manejo. Parque Nacional Galápagos, Santa Cruz, Galápagos, Ecuador.

Smallwood, K. S., D. A. Bell, S. A. Snyder, and J. E. DiDonato. 2010. Novel scavenger removal trials increase wind turbinecaused avian fatality estimates. Journal of Wildlife Management 74:1089-1097. https://doi.org/10.2193/2009-266

Snell, H. M., P. A. Stone, and H. L. Snell. 1995. Geographical characteristics of the Galapagos Islands. Noticias de Gálapagos 55:18-24. https://doi.org/10.1111/j.1365-2699.1996.tb00022.x 
Steadman, D. 2007. Extinction and biogeography of tropical Pacific birds. University of Chicago Press, Chicago, Illinois, USA.

Tanner, D., and J. Perry. 2007. Road effects on abundance and fitness of Galápagos lava lizards (Microlophus albemarlensis). Journal of Environmental Management 85:270-278. https://doi. org/10.1016/j.jenvman.2006.08.022

Tejera, G., B. Rodríguez, C. Armas, and A. Rodríguez. 2018. Wildlife-vehicle collisions in Lanzarote Biosphere Reserve, Canary Islands. PLoS ONE 13:e0192731. https://doi. org/10.1371/journal.pone.0192731

Trombulak, S. C., and C. A. Frissell. 2000. Review of ecological effects of roads on terrestrial and aquatic communities. Conservation Biology 14:18-30. https://doi.org/10.1046/

j.1523-1739.2000.99084.x

Trueman, M., and N. D'Ozouville. 2010. Characterizing the Galapagos terrestrial climate in the face of global climate change. Galapagos Research 67:26-37.

Tye, A., R. Atkinson, and V. Carrion. 2008. Increase in the number of introduced plant species in Galapagos. Galapagos Report 2006-2007:111-117.

Urquhart, B., S. Hulka, and K. Duffy. 2015. Game birds do not surrogate for raptors in trials to calibrate observed raptor collision fatalities. Bird Study 62:552-555. https://doi.org/10.1080/00063657.2015.1053751

Villa, Á. 2008. Vehicles in Galapagos. Galapagos Report 2006-2007:73-80.

Western, L., and J. O. Juvik. 1983. Roadside plant communities on Mauna Loa, Hawaii. Journal of Biogeography 10:307-316. https://doi.org/10.2307/2844740

White, G. C., and R. A. Garrott. 1990. Analysis of wildlife radiotracking data. Academic, London, UK.

Whittaker, R. J., and J. M. Fernández-Palacios. 2007. Island biogeography: ecology, evolution, and conservation. Oxford University Press, Oxford, UK.

Wiggins, I. L., and D. M. Porter. 1971. Flora of the Galápagos Islands. Stanford University Press, Stanford, California, USA. 